\title{
Efficacy of adoptive transfer of expanded fetal liver-derived precursor syngeneic and allogeneic murine NK cells against solid tumors
}

\author{
Xiaoyan Liang ${ }^{\text {** }}$, Wenqian Wang ${ }^{2}$, Guanqiao Li ${ }^{2}$, Xiaokui Zhang ${ }^{3}$, Vladimir Jankovic ${ }^{3}$, Uri Herzberg ${ }^{3}$, \\ Wolfgang Hofgartner ${ }^{3}$, Michael T Lotze
}

From 30th Annual Meeting and Associated Programs of the Society for Immunotherapy of Cancer (SITC 2015) National Harbor, MD, USA. 4-8 November 2015

\section{Introduction}

Clinical studies have demonstrated that adoptive transfer of allogeneic Natural Killer (NK) cells can play a therapeutic role in hematological malignancies and potentially solid tumors. We established and characterized ex vivo methods to obtain murine NK1.1 $1^{+}$cells from mouse fetal liver. These cells represent an orthologous cell type for expanded cells from human cord or placenta. Persistence, engraftment, expansion and anti-tumor efficacy of these fetal liver derived intermediate NK(FLiNK) cells were evaluated in allogeneic or syngeneic recipient mice after adoptive transfer. This study supports the possibility of clinical therapeutic application of ex vivo generated NK cells from HSC sources.

\section{Material and Methods}

HSC were isolated from C57BL/6(B6) fetuses (day 18-20 of gestation) using a Hematopoietic Stem Cell isolation kit and cultured with a cytokine cocktail in three stages over 21 days. FLiNK cells were harvested and characterized prior to administration. MC38-luciferase ${ }^{+}$cells $\left(2 \times 10^{5}\right)$ or Renca-luciferase $^{+}$cells were injected into recipient mice via tail vein to establish pulmonary metastasis. Tumor bearing mice received 2.5Gy irradiation followed by $5-10 \times 10^{6} \mathrm{NK}$ cells by tail vein injection and administration of rIL-2 (200,000IU/mouse, intra-peritoneal injection twice/day for 5 days). Tumor growth was measured by IVIS, lung weight, total body weight obtained, and tumor number recorded.

\section{Results}

c-kit $^{+} \mathrm{CD} 16^{-} \mathrm{NK} 1.1^{-} \mathrm{CD} 34^{-} \mathrm{NK}$ progenitor cells were successfully isolated from mouse fetal livers, and propagated over 21 days to give rise to FLiNK cells, which are CD3 ${ }^{-} \mathrm{NK} 1.1^{+} \mathrm{NKp} 46^{+} \mathrm{CD} 94^{+} \mathrm{NKG}^{2} \mathrm{D}^{+} \mathrm{KLRG}^{+} \mathrm{CD} 244^{+}$. Adoptive transfer of syngeneic FLiNK cell significantly inhibits development of mouse lung metastasis, while allogenic FLiNK showed slightly inhibitory effects. Compared with conventional splenic NK cells, FLiNK cells exhibited higher in vitro cytolytic activity against MC38 (FLiNK $30.2 \pm 4.0$ vs splenic NK $22.4 \pm 0.5$, P6 B6 FLiNK cells inhibited syngeneic MC38 tumor growth in B6 mice. Survival times were significantly prolonged from the 36 days in saline (no NK) group $(\mathrm{n}=17)$ to 50 days in FLiNK recipients $(\mathrm{n}=15),(\mathrm{p}<0.05)$. Using allogeneic Balb/c Renca tumor bearing mice, B6 FLiNK also demonstrated anti-tumor effects, with control (no NK) survival of 25 days $(n=5)$ compared with 30 days in the FLiNK group $(\mathrm{n}=5)$.

\section{Conclusions}

This study successfully established an ex vivo protocol to obtain NK1.1 $1^{+}$cells from $\mathrm{c}$-kit ${ }^{+} \mathrm{CD} 16^{-} \mathrm{NK} 1.1^{-} \mathrm{CD} 34^{-} \mathrm{NK}$ progenitor cells from the mouse fetal liver. These FLiNK cells, on adoptive transfer, inhibit development of syngeneic and allogenic mouse lung metastasis. Proposed clinical trials of allogeneic NK cells in patients with pulmonary metastatic renal cancer are in preparation.

Acknowledgements

This work was supported by Celgene Cellular Therapeutics.

'University of Pittsburgh, Pittsburgh, PA, USA

Full list of author information is available at the end of the article 


\section{Authors' details}

${ }^{1}$ University of Pittsburgh, Pittsburgh, PA, USA. ${ }^{2}$ University of Pittsburgh,

Tsinghua University, Pittsburgh, PA, USA. ${ }^{3}$ Celgene Cellular Therapeutics,

Warren, NJ, USA.

Published: 4 November 2015

doi:10.1186/2051-1426-3-S2-P30

Cite this article as: Liang et al.: Efficacy of adoptive transfer of

expanded fetal liver-derived precursor syngeneic and allogeneic murine

NK cells against solid tumors. Journal for ImmunoTherapy of Cancer 2015

3(Suppl 2):P30.

Submit your next manuscript to BioMed Central and take full advantage of:

- Convenient online submission

- Thorough peer review

- No space constraints or color figure charges

- Immediate publication on acceptance

- Inclusion in PubMed, CAS, Scopus and Google Scholar

- Research which is freely available for redistribution

Submit your manuscript at 